\title{
IMPROVISASI MODEL ARIMAX-ANFIS DENGAN VARIASI KALENDER UNTUK PREDIKSI TOTAL TRANSAKSI NON-TUNAI ${ }^{*}$
}

\author{
Muhammad Luthfi Setiarno Putera \\ Sharia Faculty, Islamic State Institute (IAIN) of Palangka Raya, Indonesia, \\ m.luthfi@iain-palangkaraya.ac.id
}

Indonesian Journal of Statistics and Its Applications (elSSN:2599-0802) Vol 4 No 2 (2020), 296 - 310

Copyright $\odot 2020$ Muhammad Luthfi Setiarno Putera. This is an open-access article distributed under the Creative Commons Attribution License, which permits unrestricted use, distribution, and reproduction in any medium, provided the original work is properly cited.

\begin{abstract}
Developed information technology boosts interest to use non-cash payment media in many areas. Following the high usage of a non-cash scheme in many payment transactions recently, the objective of this work is two-fold that is to predict the total of a non-cash transaction by using various time-series models and to compare the forecasting accuracy of those models. As a country with a mostly dense Moslem population, plenty of economical activities are arguably influenced by the Islamic calendar effect. Therefore the models being compared are ARIMA, ARIMA with Exogenous (ARIMAX), and a hybrid between ARIMAX and Adaptive Neuro-Fuzzy Inference Systems (ANFIS). By taking such calendar variation into account, the result shows that ARIMAX-ANFIS is the best method in predicting non-cash transactions since it produces lower MAPE. It is indicated that non-cash transaction increases significantly ahead of led Fitr occurrence and hits the peak in December. It demonstrates that the hybrid model can improve the accuracy performance of prediction.
\end{abstract}

Keywords: ARIMAX-ANFIS, calendar variation, hybrid model, non-cash transaction.

* Received Des 2019; Accepted Jul 2020; Published online on Jul 2020 


\section{Pendahuluan}

Transaksi ekonomi saat ini turut mengalami transisi layaknya perubahan yang terjadi pada sektor lainnya. Transisi tersebut mengarah pada makin diminatinya sistem pembayaran secara non-tunai menggunakan kartu debet dan kartu kredit (APMK) maupun uang elektronik (UE) (Wulandari et al., 2016). Dalam kurun 2014 hingga 2018, pertumbuhan nilai transaksi pembayaran non-tunai mencapai $55 \%$. Segmen media yang mencatat kenaikan paling signifikan adalah uang elektronik dengan pertumbuhan nilai transaksi sebesar 13 kali lipat (BI, 2018).

Metode yang umumnya digunakan untuk peramalan adalah Autoregressive Integrated Moving Average (ARIMA) (Box et al., 2008). Metode ARIMA dapat ditingkatkan akurasinya melalui penambahan peubah prediktor, dalam hal ini efek kalender (Al-Najaf et al., 2018). Model ARIMA dengan peubah prediktor (X) disebut sebagai ARIMA with Exogenous (ARIMAX). Cui \& Peng (2015) menemukan bahwa ARIMAX lebih unggul daripada ARIMA dan Neural Network (NN) dalam meramalkan beban listrik.

Zhang \& Qi (2005) menyatakan bahwa model ARIMA dapat dikombinasikan dengan berbagai metode non-linier, seperti NN dan ANFIS, untuk meningkatkan akurasi nilai prediksi. Adaptive Neuro Fuzzy Inference System (ANFIS) menggabungkan Fuzzy Logic dan NN dengan tujuan mengambil keuntungan dari dua pendekatan non-linier berbasis machine learning (Faulina \& Suhartono, 2013). Makridou et al. (2013) memperoleh prediksi harga emas yang dihasilkan ANFIS lebih akurat daripada ARIMA dan NN. ANFIS memiliki komponen yang serupa dengan NN, yaitu memiliki hidden layer. Namun, perbedaannya adalah ANFIS menggambarkan hubungan antar variabel dengan aturan if-then (Barak \& Sadegh, 2016). Menurut Alizadeh et al. (2012), kelebihan ANFIS daripada NN adalah arsitektur model yang mengkombinasikan pendekatan linier dan non-linier.

Di Indonesia, aktivitas perekonomian cukup unik karena terjadi peningkatan yang signifikan menjelang hari besar keagamaan, seperti Idul Fitri, pada sektor perdagangan, transportasi, hingga pariwisata (Lin et al., 2011). Mariz (2017) yang menggunakan SARIMA menyimpulkan bahwa transaksi non-tunai seringkali dipengaruhi oleh nilai pada periode sebelumnya. ARIMAX ditawarkan untuk menangkap efek kalender yang terjadi pada nilai pembayaran non-tunai dimana Aliha et al. (2019) menemukan bahwa ARIMA gagal mengidentifikasi hal tersebut di Jepang. Hibrida antara ARIMAX sebagai model linier dan ANFIS sebagai model non-linier bertujuan untuk memperbaiki kegagalan tersebut dan memperoleh model yang mampu memprediksi dengan akurat nilai transaksi (pembayaran) non-tunai di Indonesia. Terlebih penggunaan hibrida ARIMAX-ANFIS belum diterapkan pada banyak penelitian serupa di Indonesia.

\section{Metodologi}

\subsection{Data dan Peubah}

Data penelitian diakses dari portal Bank Indonesia pada menu Statistik Sistem Pembayaran. Peubah respon $(\mathrm{Y})$ adalah data total transaksi pembayaran non-tunai melalui APMK dan UE per bulan (Januari 2009 - Juni 2019). Pada penelitian ini, 
peubah $\mathrm{Y}$ memiliki satuan $\mathrm{Rp}$ triliun. Pada penelitian ini, juga dipertimbangkan peubah dummy yang mewakili variasi kalender dengan uraian sebagai berikut.

a. Peubah dummy untuk bulan Idul Fitri

Peubah ini untuk mewakili Hari Idul Fitri pada bulan ke-t dalam kalender Masehi yang dinotasikan dalam

$$
\begin{aligned}
& D_{t-2}=\left\{\begin{array}{l}
1, \text { bulan ke- }(t-2) \text { Idul Fitri (2 bulan sebelum Idul Fitri) } \\
0, \text { bulan lainnya }
\end{array}\right. \\
& D_{t-1}=\left\{\begin{array}{l}
1, \text { bulan ke- }(t-1) \text { Idul Fitri (1 bulan sebelum Idul Fitri) } \\
0, \text { bulan lainnya }
\end{array}\right. \\
& D_{t}=\left\{\begin{array}{l}
1, \text { bulan ke- } t \text { (bulan pada saat Idul Fitri) } \\
0, \text { bulan lainnya }
\end{array}\right. \\
& D_{t+1}=\left\{\begin{array}{l}
1, \text { bulan ke- }(t+1) \text { Idul Fitri (1 bulan setelah Idul Fitri) } \\
0, \text { bulan lainnya }
\end{array}\right.
\end{aligned}
$$

b. Peubah dummy untuk bulan dan minggu Idul Fitri

Peubah ini mengacu pada temuan Ahmad et al. (2015) dimana aktivitas ekonomi umumnya mencapai puncak pada bulan ke-t Idul Fitri jika 1 Syawal jatuh pada minggu ke-2, 3, dan 4. Jika Idul Fitri terjadi pada minggu ke-1 (awal bulan Masehi), maka puncak transaksi cenderung terjadi pada bulan sebelumnya.

$D_{i, t}=\left\{\begin{array}{l}1, \text { bulan ke- } t \text { (bulan pada saat Idul Fitri) pada minggu ke- } i \\ 0, \text { bulan lainnya }\end{array}\right.$

$D_{i, t-1}=\left\{\begin{array}{l}1, \text { bulan ke- }(t-1) \text { Idul Fitri pada minggu ke- } i \\ 0, \text { bulan lainnya }\end{array}\right.$

dengan $i=1,2,3,4$.

c. Peubah dummy bulanan

Peubah ini mewakili bulan dalam tahun Masehi dimana $M_{1}, M_{2}, \ldots, M_{12}$ untuk bulan Januari, Februari hingga Desember.

d. Peubah tren $t$

Peubah ini mewakili tren deterministik dan dinotasikan menjadi $t=1,2,3, \ldots, 126$. Seluruh dummy dan tren $t$ adalah peubah $\mathrm{X}$ yang dimodelkan terhadap total transaksi (pembayaran) non-tunai. Tabel 1 menyajikan periode jatuhnya Idul Fitri pada 2009-2019.

\subsection{Metode Penelitian dan Tahapan Analisis}

Pengamatan pada penelitian ini adalah berjenis runtun waktu sehingga dipilih metode yang populer untuk tujuan prediksi, seperti ARIMA. ARIMAX merupakan ekstensi dari ARIMA yang pada penelitian ini digunakan untuk menjelaskan efek kalender terhadap total transaksi pembayaran non-tunai. Sementara, hibrida ARIMAX-ANFIS sebagai model yang memperbaiki akurasi ARIMA maupun ARIMAX. Tahapan analisis data yang dilakukan adalah sebagai berikut.

1. Melakukan eksplorasi data

Analisis deskripsi visual atas plot runtun waktu guna memperoleh gambaran singkat mengenai pengaruh dari Idul Fitri terhadap total pembayaran non-tunai. 
Tabel 1. Periode Bulan, Minggu dan Tanggal Terjadinya Idul Fitri

\begin{tabular}{ccll}
\hline Waktu (t) & Tahun & \multicolumn{1}{c}{ Tanggal } & Minggu terjadinya Idul Fitri \\
\hline 9 & 2009 & 20 September & Minggu ke-3 September \\
21 & 2010 & 10 September & Minggu ke-2 September \\
32 & 2011 & 31 Agustus & Minggu ke-4 Agustus \\
44 & 2012 & 19 Agustus & Minggu ke-3 Agustus \\
56 & 2013 & 8 Agustus & Minggu ke-2 Agustus \\
67 & 2014 & 28 Juli & Minggu ke-4 Juli \\
79 & 2015 & 17 Juli & Minggu ke-3 Juli \\
91 & 2016 & 6 Juli & Minggu ke-1 Juli \\
102 & 2017 & 25 Juni & Minggu ke-4 Juni \\
114 & 2018 & 15 Juni & Minggu ke-2 Juni \\
126 & 2019 & 5 Juni & Minggu ke-1 Juni \\
\hline
\end{tabular}

Sumber : Kementerian Agama, data diolah

2. Membagi data ke dalam dua bagian, yaitu data in-sample dan data out-sample Periode data in-sample dimulai dari Januari 2009 hingga Desember 2017, sementara data out-sample dari Januari 2018 hingga Juni 2019. Data in-sample digunakan untuk membentuk model, adapun data out-sample digunakan untuk mengetahui keakuratan prediksi yang dihasilkan model.

3. Membentuk model regresi runtun waktu

Regresi runtun waktu digunakan untuk memodelkan hubungan antara peubah respon $y_{t}$ dan $k$ peubah prediktor $X_{1}, X_{2}, \ldots, X_{k}$ mengacu pada runtun waktu yang stokastik dengan $t=1,2, \ldots, n$ (Ahmad et al., 2015). Model regresi runtun waktu dengan variasi kalender yang memuat tren deterministik $t$ dan pola musiman dinyatakan pada persamaan (1)

$$
y_{t}=\beta_{0}+\beta_{1} M_{1, t}+\ldots \beta_{s} M_{s, t}+\delta t+\gamma_{1} L_{t}+\ldots \gamma_{m} L_{t-m}+\ldots+\gamma_{n} L_{t+n}+\varepsilon_{t} \text {, }
$$

dengan

$$
\begin{array}{ll}
\beta_{1}, \beta_{2}, \ldots, \beta_{s} & : \text { parameter peubah dummy untuk musiman } \\
M_{1, t}, M_{2, t}, \ldots, M_{\mathrm{s}, t} & : \text { peubah dummy musiman } \\
\gamma_{1}, \gamma_{2}, \ldots, \gamma_{m}, \ldots, \gamma_{n} & : \text { parameter peubah dummy kalender } \\
L_{t}, L_{t-m}, \ldots, L_{t+n} & : \text { peubah dummy kalender. }
\end{array}
$$

4. Membentuk model ARIMA

Autoregressive Integrated Moving Average (ARIMA) adalah kombinasi dari model AR ber-orde $p$ dengan MA ber-orde $q$ yang mengalami pembedaan (differencing) ber-orde $d$ untuk data runtun waktu regular (Box et al., 2008). Model ARIMA reguler dapat direpresentasikan dalam persamaan (2),

$$
\phi_{p}(B)(1-B)^{d} y_{t}=\theta_{q}(B) \varepsilon_{t} \text {. }
$$

Aktivitas ekonomi, baik perdagangan, transportasi dan jumlah wisatawan umumnya meningkat atau menurun pada masa tertentu (Lin et al., 2011). Hal ini mengindikasikan hadirnya pola musiman pada data tersebut. Model ARIMA 
untuk pola musiman disebut Seasonal ARIMA (SARIMA) atau ARIMA dengan musiman. ARIMA dengan musiman dapat dinotasikan ke dalam persamaan (3)

$\phi_{p}(B) \Phi_{P}\left(B^{S}\right)(1-B)^{d}\left(1-B^{S}\right)^{D} y_{t}=\theta_{q}(B) \Theta_{Q}\left(B^{S}\right) \varepsilon_{t}$,

dengan

$$
\begin{aligned}
& \phi_{p}(B)=1-\phi_{1} B-\phi_{2} B^{2}-\ldots-\phi_{p} B^{p} \\
& \Phi_{P}\left(B^{S}\right)=1-\Phi_{1} B^{S}-\Phi_{2} B^{2 S}-\ldots-\Phi_{P} B^{P S} \\
& \theta_{q}(B)=1-\theta_{1} B-\theta_{2} B^{2}-\ldots-\theta_{q} B^{q} \\
& \Theta_{Q}\left(B^{S}\right)=1-\Theta_{1} B^{S}-\Theta_{2} B^{2 S}-\ldots-\Theta_{Q} B^{Q S} .
\end{aligned}
$$

Notasi $S$ adalah periode musiman, $B$ adalah operator backshift, dan $\varepsilon_{t}$ adalah galat dengan mean 0 dan varians konstan yang white-noise.

5. Membentuk model ARIMAX

ARIMA with Exogenous (ARIMAX) adalah ARIMA yang melibatkan peubah prediktor $X$ untuk memodelkan peubah respon $Y$ (Ahmad et al., 2015). Penelitian ini menggunakan model ARIMAX dengan peubah dummy variasi kalender dan peubah deterministik yang diwakili oleh dummy bulanan $M$ dan tren tahun $t$, dengan formulasi ditunjukkan dalam persamaan (4)

$$
y_{t}=\delta_{1} t+\sum_{s} \beta_{s} M_{s, t}+\sum_{i} \gamma_{i} D_{i, t}+\sum_{i} \varphi_{i} D_{i, t-1}+\frac{\theta_{q}(B)}{\phi_{p}(B)(1-B)^{d}} \varepsilon_{t}
$$

6. Membentuk model hibrida ARIMAX-ANFIS

Model ARIMAX-ANFIS adalah hibrida (kombinasi) antara ARIMAX sebagai model linier dan ANFIS sebagai model non-linier (Diarsih et al., 2019). Konsep kerja model hibrida dapat diformulasikan dalam persamaan (5)

$$
y_{t}=L_{t}+N_{t}+\varepsilon_{t} \text {, }
$$

dengan $L$ dan $N$ masing-masing mewakili linier dan non-linier. Taksiran $L_{t}$ diperoleh dari model ARIMAX sedemikian hingga diperoleh galat model ARIMAX $a_{t}$. Galat $a_{t}$ kemudian dimodelkan dengan ANFIS untuk meningkatkan performansi ARIMAX (Tarno et al., 2013).

Sebagai salah satu pendekatan non-linier, Adaptive Neuro-Fuzzy Inference System (ANFIS) memiliki arsitektur yang menggabungkan Neural Network (NN) dan Fuzzy Inference System (FIS). ANFIS memiliki konsep aturan jika-maka (ifthen) (Boyacioglu \& Avci, 2010). Salah satu model fuzzy yang diterapkan pada arsitektur ANFIS adalah Takagi-Sugeno-Kang (TSK) (Kristiana et al., 2015; Tarno et al., 2013). Dengan mengasumsikan struktur FIS memodelkan dua input $\mathrm{a}_{1, t,} \mathrm{a}_{2, t}$ dan satu output $\mathrm{a}_{t}$, aturan if-then model TSK yang berlaku menurut Makridou et al. (2013) adalah sebagai berikut,

Aturan 1 : Jika $\mathrm{a}_{1, t}$ adalah A1 dan a $2, t$ adalah B1, maka $f_{1}=p_{1} a_{1, t}+q_{1} a_{2, t}+r_{1}$, Aturan 2 : Jika $\mathrm{a}_{1, t}$ adalah A2 dan a2,t adalah B2, maka $f_{2}=p_{2} a_{1, t}+q_{2} a_{2, t}+r_{2}$. Berikut ini merupakan lima lapisan (layer) arsitektur ANFIS untuk dua input, satu output dengan dua aturan $\mathrm{A}$ dan $\mathrm{B}$. 
Lapisan 1: Tiap simpul pada lapisan ini adalah simpul adaptif dengan fungsi simpul diberikan dalam persamaan (6).

$$
\begin{aligned}
& O_{1, j}=\mu_{A_{j}}\left(a_{1}\right), j=1,2 \\
& O_{1, j}=\mu_{B_{j}}\left(a_{2}\right), j=1,2
\end{aligned}
$$

dengan $a_{j}$ merupakan input bagi simpul $j$ dan A dan B merupakan nilai linguistik bagi input. Simbol $O_{1, j}$ merepresentasikan fungsi keanggotaan. Misalkan fungsi keanggotaan adalah Gaussian, maka berlaku

$$
\mu(a)=\exp \left(-\frac{1}{2}\left(\frac{a-\mu}{\sigma}\right)^{2}\right) \text {. }
$$

dengan $\mu$ dan $\sigma$ berperan sebagai parameter premis.

Lapisan 2: Tiap simpul di lapisan ini umumnya ditandai sebagai $\pi$ karena mengalikan sinyal-sinyal yang masuk dan berlaku persamaan (7)

$$
O_{2, j}=w_{j}=\mu_{A_{j}}\left(a_{1}\right) \cdot \mu_{B_{j}}\left(a_{2}\right), j=1,2
$$

Lapisan 3: Tiap simpul di lapisan ini dilabeli sebagai $\mathrm{N}$ yang dinyatakan dalam persamaan (8) berikut

$$
O_{3, j}=\widehat{w}_{j}=\frac{w_{j}}{\sum_{j=1}^{2} w_{j}}, j=1,2 .
$$

Lapisan 4: Tiap simpul di lapisan ini memiliki fungsi dan dinyatakan dalam persamaan (9)

$$
O_{4, j}=\widehat{w}_{j} \cdot f_{j}=\widehat{w}_{j}\left(p_{j} a_{1, t}+q_{j} a_{2, t}+r_{j}\right), j=1,2
$$

dengan $p$, $q$, dan $r$ merupakan parameter konsekuen dari tiap simpul.

Lapisan 5: Lapisan ini tersusun atas satu simpul dengan simbol $\Sigma$ yang menjumlahkan seluruh sinyal yang masuk dengan formulasi disajikan dalam persamaan (10)

$$
O_{5, j}=\sum_{j} \widehat{w}_{j} f_{j}=\frac{\sum_{j} w_{j} f_{j}}{\sum_{j} w_{j}}, j=1,2 .
$$

Jika parameter premis sudah ditetapkan (fixed), maka luaran ANFIS adalah kombinasi linier dari parameter konsekuen. Algoritma ANFIS bersifat hybrid dimana forward step berlaku untuk parameter konsekuen, sementara backward step berlaku untuk parameter premis (lokasi dan bentuk) (Tarno et al., 2018). Input bagi ANFIS diseleksi menggunakan PACF galat $a_{t}$ yang signifikan pada lag tertentu (Diarsih et al., 2019; Kristiana et al., 2015). Hasil pemodelan $\hat{N}_{t}$ sehingga diperoleh model prediksi hibrida ARIMAX-ANFIS $\hat{y}_{t}$ dalam persamaan (11)

$$
\hat{y}_{t}=\hat{L}_{t}+\hat{N}_{t} \text {. }
$$


7. Melakukan pemilihan model terbaik berdasarkan indikator MAPE.

Model dengan akurasi yang lebih baik biasanya memiliki Mean Absolute Percentage Error (MAPE) yang lebih kecil (Ahmad et al., 2015). Alasan penggunaan MAPE karena nilai transaksi non-tunai jauh melebihi angka 0.

8. Memprediksi total transaksi pembayaran non-tunai.

Prediksi antara model ARIMAX dan ARIMAX-ANFIS diestimasi dan dibandingkan dalam grafik plot runtun waktu untuk memeriksa kebaikan prediksi.

\section{Hasil dan Pembahasan}

\subsection{Eksplorasi Data}

Amatan atas transaksi non-tunai, mulai dari Januari 2009 hingga Juni 2019, adalah sebanyak 126 bulan. Fluktuasi total transaksi dapat dilihat pada Gambar 1.

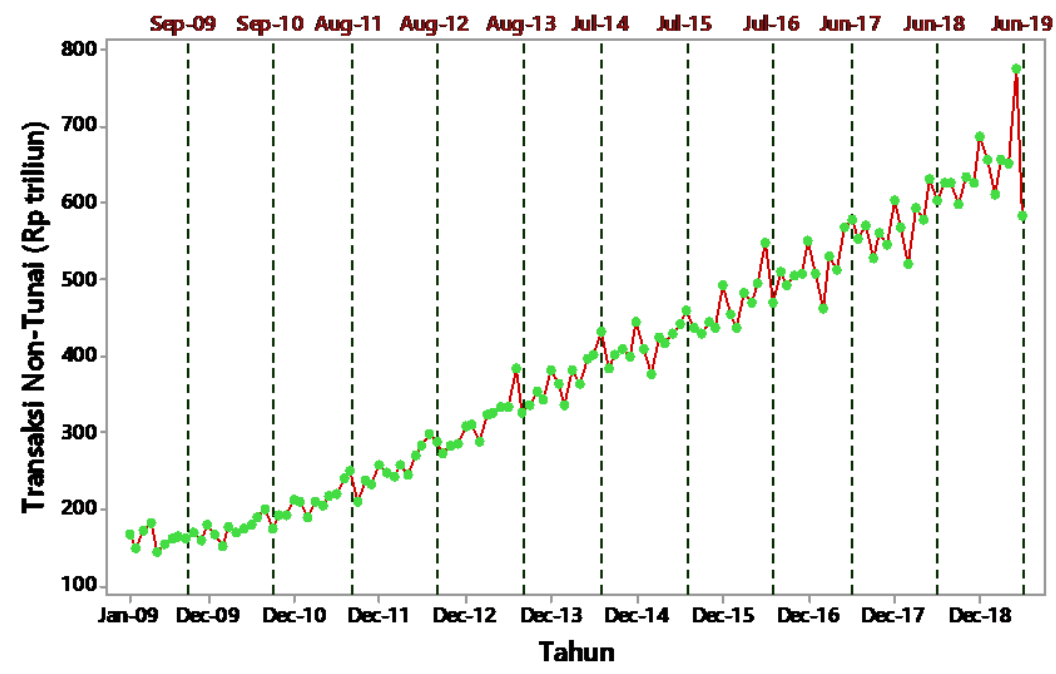

Gambar 1. Plot Runtun Waktu untuk Transaksi Non-Tunai

Total transaksi non-tunai dalam Gambar 1 mengalami kenaikan yang tajam tepat pada bulan jatuhnya Hari Idul Fitri, antara lain pada tahun 2011 dan 2014. Ketika Idul Fitri terjadi pada awal bulan, peningkatan pada transaksi non-tunai justru terjadi 1 bulan sebelumnya, antara lain pada tahun 2013 dan 2016. Selain itu, peningkatan transaksi non-tunai dapat terjadi 2 bulan sebelum Idul Fitri, seperti pada tahun 2010 dan 2016. Dari Gambar 1 juga ditunjukkan bahwa bulan Desember (akhir tahun) selalu menghasilkan nilai transaksi non-tunai tertinggi.

\subsection{Model Regresi Runtun Waktu untuk Transaksi Non-Tunai}

Persamaan (12) menyajikan model regresi runtun waktu untuk transaksi pembayaran non-tunai pada data in-sample dengan estimasi parameter OLS. 


$$
\begin{aligned}
\hat{Y}_{t}= & 4,15 t-2,17 D_{t-2}+12,3 D_{t-1}+26,8 D_{t}-2,97 D_{t+1}-54,7 D_{1, t}-41,6 D_{2, t}- \\
& 16,5 D_{3, t}+49,1 D_{1, t-1}+7,1 D_{2, t-1}-4,7 D_{3, t-1}+111,07 M_{1}+83,98 M_{2}+ \\
& 116,23 M_{3}+104,61 M_{4}+115,09 M_{5}+112,33 M_{6}+120,81 M_{7}+ \\
& 110,1 M_{8}+97,98 M_{9}+109,64 M_{10}+98,92 M_{11}+131,42 M_{12}
\end{aligned}
$$

Dengan $\alpha$ sebesar $5 \%$, peubah dummy yang signifikan pada model adalah $D_{t}$, $D_{1, t}, \quad D_{2, t}, D_{1, t-1}$, dan seluruh dummy bulanan sebanyak 12 parameter. Selain itu, peubah tren $t$ memiliki pengaruh yang signifikan terhadap transaksi non-tunai. Artinya, nilai transaksi non-tunai terbukti secara statistik meningkat tiap tahun.

Dengan koefisien $D_{t}$ sebesar 26,8, terjadinya Idul Fitri berpengaruh positif terhadap total transaksi non-tunai tepat pada bulan jatuhnya Idul Fitri. Adapun $D_{1, t}$ dan $D_{2, t}$ yang bernilai negatif mengindikasikan transaksi non-tunai menurun dibandingkan bulan sebelumnya saat Idul Fitri jatuh pada minggu ke-1 dan ke-2. Selain itu, bulan Desember (akhir tahun) juga menjadi periode bulan dengan nilai transaksi non-tunai tertinggi, terlihat dari nilai koefisien $M_{12}$ sebesar 131,42.

\subsection{Model ARIMA dan ARIMAX untuk Transaksi Non-Tunai}

Sebelum dimodelkan dengan ARIMA, terlebih dulu diperiksa apakah data transaksi non-tunai telah stasioner. Berdasarkan uji Augmented Dickey-Fuller (ADF), total transaksi non-tunai terbukti tidak stasioner dalam mean sehingga perlu dilakukan pembedaan dengan orde $d$ sebesar 1 .

Dengan identifikasi ACF dan PACF pada data yang sudah diproses, terdapat 3 model ARIMA yang diduga relevan dan tepat, yaitu $\operatorname{ARIMA}(0,1,1)(1,0,0)^{12}$, $\operatorname{ARIMA}(0,1,2)(1,0,0)^{12}$, dan $\operatorname{ARIMA}(1,1,1)(1,0,0)^{12}$. Tabel 2 menyajikan signifikansi parameter dan nilai AIC dari tiap model SARIMA untuk data in-sample.

Tabel 2. Signifikansi Parameter Model SARIMA

\begin{tabular}{clccc}
\hline \multicolumn{1}{c}{ Model } & \multicolumn{1}{c}{ Parameter } & Koefisien & $p$-value & AIC \\
\hline \multirow{2}{*}{ ARIMA $(0,1,1)(1,0,0)^{12}$} & $\mathrm{MA}(1)$ & 0,73 & $<0,0001$ & \multirow{2}{*}{ (1) } \\
& $\mathrm{AR}(1)$ musiman & 0,92 & $<0,0001$ & \\
& $\mathrm{MA}(1)$ & 0,94 & $<0,0001$ & \\
ARIMA $(0,1,2)(1,0,0)^{12}$ & $\mathrm{MA}(2)$ & $-0,26$ & 0,0075 & 879,63 \\
& $\mathrm{AR}(1)$ musiman & 0,94 & $<0,0001$ & \\
& $\mathrm{AR}(1)$ & $-0,30$ & 0,016 & \\
ARIMA $(1,1,1)(1,0,0)^{12}$ & $\mathrm{MA}(1)$ & 0,62 & $<0,0001$ & 880,77 \\
& $\mathrm{AR}(1)$ musiman & 0,93 & $<0,0001$ & \\
\hline
\end{tabular}

Tabel 2 menunjukkan bahwa seluruh parameter pada tiga opsi model ARIMA signifikan pada $\alpha=5 \%$. Artinya, transaksi pembayaran non-tunai terbukti secara statistik dipengaruhi pula oleh transaksi pada bulan sebelumnya serta galat bulan sebelumnya. Model yang lebih sederhana dan tepat berdasarkan AIC terkecil adalah $\operatorname{ARIMA}(0,1,2)(1,0,0)^{12}$ dengan model ditunjukkan pada persamaan (13)

$$
y_{t}=y_{t-1}+0,937 y_{t-12}-0,937 y_{t-13}+\varepsilon_{t}+0,942 \varepsilon_{t-1}-0,263 \varepsilon_{t-2}
$$


Langkah berikutnya adalah membangun model ARIMAX. Dalam penelitian ini, ARIMAX dibangun terlebih dulu melalui regresi deret waktu dengan model yang mengacu pada persamaan (12). Konsep utama ARIMAX terletak pada galat model persamaan (12) tersebut. Galat model regresi deret waktu akan dimodelkan kembali dengan ARIMA, lalu ditambahkan dengan hasil estimasi regresi deret waktu. Tabel 3 menyajikan ringkasan MAPE seluruh opsi model ARIMAX untuk data in-sample.

Tabel 3. MAPE Model ARIMAX untuk Data In-Sample

\begin{tabular}{cccccc}
\hline Model & $\begin{array}{c}\text { MAPE } \\
(\%)\end{array}$ & Model & $\begin{array}{c}\text { MAPE } \\
(\%)\end{array}$ & Model & $\begin{array}{c}\text { MAPE } \\
(\%)\end{array}$ \\
\hline $\operatorname{ARIMAX}(0,1,1)$ & 2,92 & $\operatorname{ARIMAX}(2,1,1)$ & 2,88 & $\operatorname{ARIMAX}(2,1,0)$ & 2,82 \\
$\operatorname{ARIMAX}(1,1,0)$ & 2,92 & $\operatorname{ARIMAX}(1,1,2)$ & 2,91 & & \\
\hline
\end{tabular}

Dari Tabel 3, ditunjukkan bahwa ARIMAX $(2,1,0)$ memiliki nilai MAPE terkecil. Jadi, model in-sample terbaik adalah $\operatorname{ARIMAX}(2,1,0)$ yang disajikan dalam persamaan (14).

$$
\begin{aligned}
\hat{Y}_{t}= & 4,15 t-2,17 D_{t-2}+12,3 D_{t-1}+26,8 D_{t}-2,97 D_{t+1}-54,7 D_{1, t}-41,6 D_{2, t}- \\
& 16,5 D_{3, t}+49,1 D_{1, t-1}+7,1 D_{2, t-1}-4,7 D_{3, t-1}+111,07 M_{1}+83,98 M_{2}+ \\
& 116,23 M_{3}+104,61 M_{4}+115,09 M_{5}+112,33 M_{6}+120,81 M_{7}+110,1 M_{8}+ \\
& 97,98 M_{9}+109,64 M_{10}+98,92 M_{11}+131,42 M_{12}+\frac{1}{\left(1+0,602 B+0,233 B^{2}\right)(1-B)} \varepsilon_{t}
\end{aligned}
$$

Selanjutnya, ARIMAX $(2,1,0)$ akan dihibrida dengan ANFIS.

\subsection{Model Hibrida ARIMAX-ANFIS untuk Transaksi Non-Tunai}

Teknik clustering yang digunakan pada penelitian ini adalah grid partitioning sehingga tidak terbatas pada salah satu fungsi keanggotaan saja. Dalam penelitian ini, input model ANFIS berasal dari galat model ARIMAX persamaan (14). Salah satu teknik untuk menyeleksi input yang akan dimodelkan dengan ANFIS dapat melalui identifikasi PACF. PACF galat ARIMAX lag $k$ yang signifikan dapat menjadi input bagi ANFIS (Kristiana et al, 2015; Diarsih et al, 2019). Gambar 2 menampilkan PACF galat ARIMAX $(2,1,0)$ sebagai model in-sample terbaik.

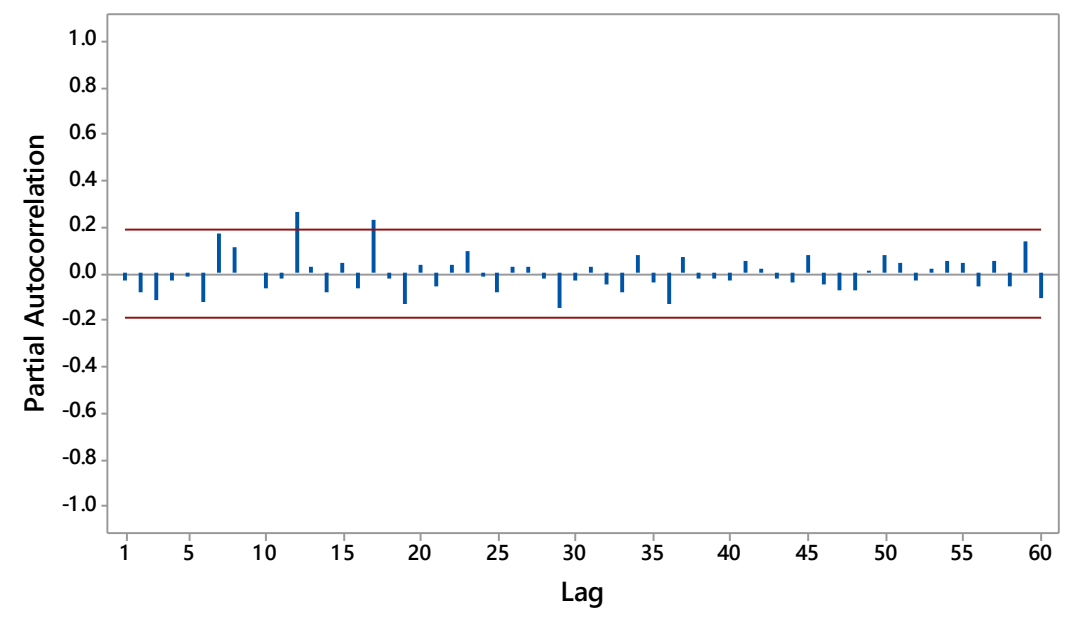

Gambar 2. PACF Model In-Sample ARIMAX(2,1,0) 
Dari Gambar 2 diperoleh bahwa galat lag-12 dan lag-17 signifikan (cut-off), terlihat dari garis yang keluar dari batas signifikansi. Hal ini tidak diperkenankan dalam prediksi karena PACF galat pada seluruh lag idealnya tidak signifikan (menunjukkan sifat white noise dan tidak lagi terindikasi adanya galat yang melanggar asumsi). Dalam aplikasi ARIMAX-ANFIS, beberapa model in-sample masing-masing akan dibandingkan untuk memperoleh model yang dianggap terbaik dalam aspek akurasi prediksi. Tabel 4 menyajikan MAPE dari hibrida ARIMAX(2,1,0)-ANFIS yang menggunakan beberapa opsi fungsi keanggotaan dengan berbagai jumlah linguistik. Input yang digunakan adalah galat lag-12 dan lag17.

Tabel 4. MAPE Model ARIMAX-ANFIS untuk Data In-Sample

\begin{tabular}{lccccc}
\hline $\begin{array}{c}\text { Fungsi } \\
\text { Keanggotaan }\end{array}$ & $\begin{array}{c}\text { Jumlah } \\
\text { Linguistik }\end{array}$ & MAPE (\%) & $\begin{array}{c}\text { Fungsi } \\
\text { Keanggotaan }\end{array}$ & $\begin{array}{c}\text { Jumlah } \\
\text { Linguistik }\end{array}$ & MAPE (\%) \\
\hline Triangle & $(2,2)$ & 2,79 & Gaussian & $(2,2)$ & 2,92 \\
& $(3,3)$ & 2,15 & & $(3,3)$ & 2,94 \\
& $(4,4)$ & 2,09 & & $(4,4)$ & 2,25 \\
\hline Trapezoid & $(2,2)$ & 2,28 & Sigmoid & $(2,2)$ & 2,85 \\
& $(3,3)$ & $2,08^{*}$ & & $(3,3)$ & 2,86 \\
& $(4,4)$ & 2,32 & & $(4,4)$ & 2,85 \\
\hline
\end{tabular}

Tabel 4 mengindikasikan bahwa fungsi keanggotaan yang menghasilkan prediksi paling akurat untuk data in-sample adalah Trapezoid dengan jumlah linguistik sebanyak 3 di masing-masing input. Hal ini dikarenakan model ARIMAX-ANFIS Trapezoid(3,3) menghasilkan MAPE terendah, yaitu sebesar 2,08\%. Jika dibandingkan dengan MAPE ARIMAX pada Tabel 3, dapat dikatakan bahwa ARIMAX-ANFIS lebih akurat dalam menghasilkan prediksi atas transaksi non-tunai untuk data in-sample.

\subsection{Pemilihan Model Terbaik}

Dalam teori peramalan, pemeriksaan asumsi galat seringkali direkomendasikan dilakukan sebelum melakukan perbandingan antar model dalam pemilihan model terbaik. Asumsi yang disyaratkan adalah apakah galat model ARIMA, ARIMAX dan hibrida ARIMAX-ANFIS white noise, independen dan berdistribusi normal. Tabel 5 menyajikan hasil pemeriksaan asumsi galat untuk data in-sample. Sebagai ilustrasi, ARIMAX-ANFIS hanya diwakili 4 model in-sample dengan MAPE terendah, yaitu Trapezoid $(3,3)$, Triangle $(3,3)$, Triangle $(4,4)$ dan Gaussian $(4,4)$.

Berdasarkan Tabel 5, dapat dikatakan bahwa sebagian besar model memenuhi asumsi IIDN. Selanjutnya adalah memilih model terbaik didasari atas nilai MAPE terendah. Tabel 6 dan 7 menyajikan MAPE dari seluruh alternatif model, kecuali model regresi deret waktu. 
Tabel 5. Pemenuhan Asumsi IIDN pada Model In-Sample

\begin{tabular}{lllll}
\hline \multicolumn{2}{c}{ Alternatif model } & $\begin{array}{c}\text { Asumsi white } \\
\text { noise }\end{array}$ & $\begin{array}{c}\text { Asumsi } \\
\text { independen }\end{array}$ & $\begin{array}{c}\text { Asumsi } \\
\text { normalitas }\end{array}$ \\
\hline \multirow{2}{*}{ ARIMA } & ARIMA $(0,1,1)(1,0,0)^{12}$ & Memenuhi & Memenuhi & Memenuhi \\
& ARIMA $(0,1,2)(1,0,0)^{12}$ & Memenuhi & Memenuhi & Memenuhi \\
& ARIMA $(1,1,1)(1,0,0)^{12}$ & Memenuhi & Memenuhi & Memenuhi \\
\hline \multirow{6}{*}{ ARIMAX } & ARIMAX $(0,1,1)$ & Memenuhi & Memenuhi & Memenuhi \\
& ARIMAX $(1,1,0)$ & Memenuhi & Memenuhi & Memenuhi \\
& ARIMAX $(2,1,0)$ & Memenuhi & Memenuhi & Tidak \\
& ARIMAX $(2,1,1)$ & Memenuhi & Memenuhi & Memenuhi \\
& ARIMAX $(1,1,2)$ & Memenuhi & Memenuhi & Memenuhi \\
\hline \multirow{4}{*}{ ARIMAX- } & Trapezoid(3,3) & Memenuhi & Memenuhi & Memenuhi \\
ANFIS & Triangle(3,3) & Memenuhi & Memenuhi & Memenuhi \\
& Gaussian(4,4) $(4,4)$ & Memenuhi & Memenuhi & Tidak \\
& Gemuhi & Tidak & & Memenuhi \\
\end{tabular}

Tabel 6. Perbandingan MAPE Model In-Sample dan Out-Sample

\begin{tabular}{llcc}
\hline \multirow{2}{*}{ Model } & \multicolumn{2}{c}{ MAPE $(\%)$} \\
\cline { 3 - 4 } ARIMA & In-sample & Out-sample \\
\hline \multirow{6}{*}{ ARIMAX } & ARIMA $(0,1,1)(1,0,0)^{12}$ & 3,73 & 5,26 \\
& ARIMA $(0,1,2)(1,0,0)^{12}$ & 3,61 & 5,47 \\
& ARIMA $(1,1,1)(1,0,0)^{12}$ & 3,65 & 5,40 \\
\hline & ARIMAX $(0,1,1)$ & 2,92 & 3,31 \\
& ARIMAX $(1,1,0)$ & 2,92 & 3,07 \\
& ARIMAX $(2,1,0)$ & 2,82 & 3,14 \\
& ARIMAX(2,1,1) & 2,88 & 3,01 \\
& ARIMAX(1,1,2) & 2,91 & 3,30 \\
\hline
\end{tabular}

Tabel 6 menunjukkan bahwa ARIMAX dengan variasi kalender sebagai eksogen mampu memperbaiki akurasi prediksi total transaksi non-tunai, baik pada data insample yang digunakan untuk membangun model maupun pada data out-sample untuk melihat kebaikan model dalam memprediksi.

Adapun Tabel 7 mengindikasikan bahwa ARIMAX(2,1,0)-ANFIS dengan fungsi keanggotaan tertentu menghasilkan akurasi yang lebih baik daripada ARIMAX. Khusus untuk data out-sample, model ARIMAX(2,1,0)-ANFIS Sigmoid (2,2) adalah yang terbaik karena menghasilkan MAPE yang terkecil di antara seluruh alternatif model, yaitu sebesar $2,87 \%$.

Dari pemodelan yang telah dilakukan, parameter pada model terbaik ARIMAXANFIS adalah kombinasi persamaan (14) dan galat yang dimodelkan dengan ANFIS clustering sigmoid $(2,2)$. Pemaknaan terhadap model adalah nilai transaksi non-tunai cenderung bertambah $\mathrm{Rp} 4,15$ triliun per bulannya dimana peningkatan transaksi non-tunai adalah sebesar Rp 12,3 triliun sebulan sebelum Lebaran dan peningkatan lebih tinggi pada bulan jatuhnya hari Lebaran sebesar Rp 26,8 triliun. 
Persamaan model terbaik juga mengindikasikan bahwa jika Lebaran terjadi pada minggu pertama di bulan tertentu, maka peningkatan nilai transaksi justru terjadi di 1 bulan sebelumnya sebesar Rp 49,1 triliun. Dan jika Lebaran terjadi pada minggu kedua, peningkatan nilai transaksi juga dialami pada bulan sebelumnya meski peningkatannya lebih kecil, yaitu Rp 7,1 triliun. Hal menarik lainnya yang diperoleh dari model terbaik adalah masing-masing bulan memiliki kontribusi berbeda terhadap besar-kecilnya nilai transaksi non-tunai. Bulan dengan kontribusi transaksi non-tunai terendah adalah Februari, yaitu sebesar Rp 83,98 triliun. Sedangkan bulan dengan kontribusi transaksi non-tunai terendah adalah Februari, yaitu sebesar Rp 131,42 triliun.

Tabel 7. Nilai MAPE Model ARIMAX-ANFIS In-Sample dan Out-Sample

\begin{tabular}{|c|c|c|c|c|c|}
\hline \multirow{2}{*}{$\begin{array}{l}\text { ARIMAX- } \\
\text { ANFIS }\end{array}$} & \multicolumn{2}{|c|}{ MAPE (\%) } & \multirow{2}{*}{$\begin{array}{l}\text { ARIMAX- } \\
\text { ANFIS }\end{array}$} & \multicolumn{2}{|c|}{ MAPE(\%) } \\
\hline & $\begin{array}{c}\text { In- } \\
\text { sample }\end{array}$ & $\begin{array}{c}\text { Out- } \\
\text { sample }\end{array}$ & & $\begin{array}{c}\text { In- } \\
\text { sample }\end{array}$ & $\begin{array}{c}\text { Out- } \\
\text { sample }\end{array}$ \\
\hline Triangle(2,2) & 2,79 & 3,36 & Gaussian(2,2) & 2,92 & 3,25 \\
\hline Triangle(3,3) & 2,15 & 3,14 & Gaussian(3,3) & 2,94 & 3,00 \\
\hline Triangle $(4,4)$ & 2,09 & 3,28 & Gaussian $(4,4)$ & 2,25 & 3,20 \\
\hline Trapezoid(2,2) & 2,28 & 3,30 & Sigmoid(2,2) & 2,85 & $2,87^{*}$ \\
\hline Trapezoid(3,3) & $2,08^{*}$ & 3,08 & Sigmoid(3,3) & 2,86 & 3,03 \\
\hline Trapezoid(4,4) & 2,32 & 3,24 & Sigmoid(4,4) & 2,85 & 3,02 \\
\hline
\end{tabular}

Ket. * Model dengan MAPE terendah

Temuan menarik lainnya dari model ARIMAX-ANFIS terbaik adalah terdapat faktor di luar peubah tren dan efek kalender yang belum teridentifikasi yang mempengaruhi nilai transaksi pada 12 bulan yang lalu dan 17 bulan yang lalu. Tetapi, hal ini sudah direduksi pengaruhnya melalui pemodelan galat dengan ANFIS sehingga akurasi model relatif baik dalam memprediksi transaksi non-tunai.

\subsection{Prediksi Total Transaksi Non-Tunai}

Setelah memperoleh model out-sample terbaik untuk prediksi total transaksi nontunai, Gambar 5 memberikan visual mengenai pola prediksi yang dihasilkan oleh ARIMAX dan ARIMAX-ANFIS terbaik untuk data out-sample. ARIMAX diwakili ARIMAX $(2,1,1)$, adapun ARIMAX-ANFIS diwakili model $\operatorname{ARIMAX}(2,1,0)$ dengan fungsi keanggotaan dan cluster ANFIS berupa Sigmoid $(2,2)$.

Gambar 5 mengindikasikan bahwa model ARIMAX-ANFIS lebih akurat daripada ARIMAX. Prediksi yang dihasilkan ARIMAX-ANFIS, terutama pada akhir 2018 dan tahun 2019, konsisten lebih dekat dengan nilai transaksi non-tunai yang aktual. Di bulan-bulan tertentu, antara lain Mei 2018 dan Maret 2019, prediksi ARIMAX-ANFIS tergolong sangat akurat sebab selisih antara nilai aktual dan nilai prediksi mendekati 0. Selain itu, model ARIMAX-ANFIS juga mampu memprediksi total transaksi nontunai lebih akurat pada bulan menjelang terjadinya Idul Fitri (Mei 2018 dan Mei 2019) maupun akhir tahun (Desember 2018). Pola dan tren (pergerakan) nilai aktual juga konsisten diimbangi oleh model hibrida ARIMAX-ANFIS. Melalui hasil pengujian, galat ARIMAX-ANFIS pada model prediksi terbukti tidak melanggar asumsi, baik 
asumsi white noise dan asumsi normalitas. Sementara itu, asumsi independen tidak dapat dibuktikan terpenuhi karena jumlah observasi yang kurang, hanya sebanyak 18 bulan.

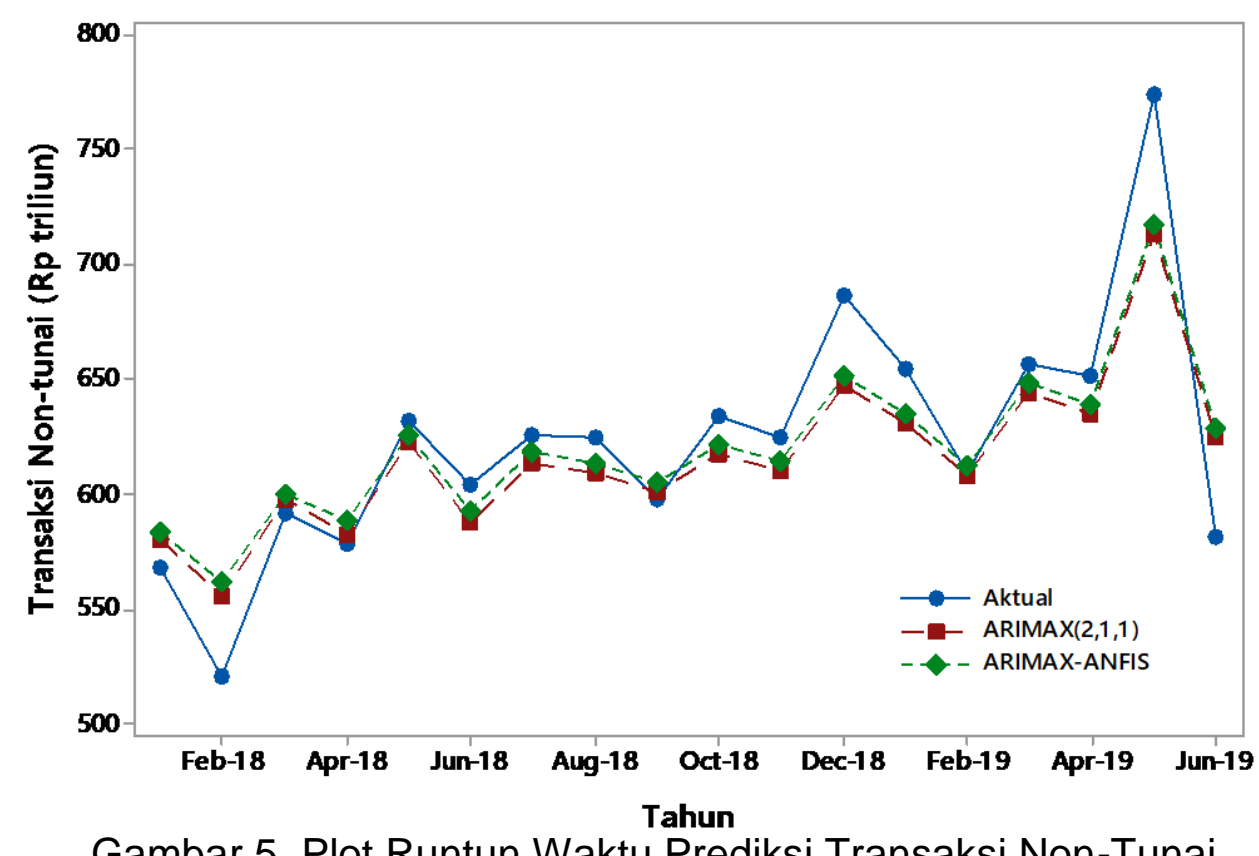

\section{Simpulan}

Aktivitas perekonomian umumnya mengalami peningkatan pada waktu tertentu, seperti menjelang hari besar keagamaan Idul Fitri ataupun akhir tahun. Adapun penanggalan Masehi berbeda dengan penanggalan Hijriah sehingga ada kecenderungan terjadinya perbedaan dinamika transaksi non-tunai di Indonesia secara tahunan untuk bulan yang sama. Penelitian ini menghasilkan kesimpulan dimana model ARIMAX-ANFIS menghasilkan prediksi total transaksi non-tunai yang lebih akurat daripada ARIMA musiman (SARIMA) dan ARIMAX. Model ARIMAXANFIS juga mampu memprediksi total transaksi non-tunai lebih akurat pada periode menjelang Idul Fitri (Mei 2018 dan Mei 2019) maupun akhir tahun (Desember 2018). Keunggulan ARIMAX-ANFIS lainnya adalah konsistensi dalam mengikuti tren dan fluktuasi total transaksi non-tunai secara aktual. Rekomendasi untuk penelitian selanjutnya adalah menggunakan optimalisasi Particle Swarm Optimization (PSO) untuk meningkatkan performansi ANFIS sehingga akurasi prediksi makin tinggi. Dapat pula dipertimbangkan untuk menggunakan teknik seleksi input seperti regresi stepwise maupun analisis cluster/gerombol.

\section{Daftar Pustaka}

Ahmad, I. S., Setiawan, Suhartono, \& Masun, N. H. (2015). Forecasting of monthly inflow and outflow currency using time series regression and ARIMAX: The Idul Fitri effect. AIP Conference Proceedings, 1691(1), 050002. AIP Publishing LLC. 
Aliha, P. M., Sarmidi, T., \& Said, F. F. (2019). The Effect of Financial Innovation on the Forecasting Performance of Money Demand in Japan in the Context of ARIMA Model during 1990-2015. International Journal of Business and Economy, 1(2): 78-94.

Alizadeh, M., Jolai, F., Aminnayeri, M., \& Rada, R. (2012). Comparison of different input selection algorithms in neuro-fuzzy modeling. Expert Systems with Applications, 39(1): 1536-1544.

Al-Najaf, F. A. S. I., Salehi, M., \& Al-Maliki, H. S. N. (2018). The effect of Islamic sacred months on stock prices in Iran and Iraq Stock Exchanges. ISRA International Journal of Islamic Finance, 10(1): 111-119.

Barak, S., \& Sadegh, S. S. (2016). Forecasting energy consumption using ensemble ARIMA-ANFIS hybrid algorithm. International Journal of Electrical Power \& Energy Systems, 82: 92-104.

[BI] Bank Indonesia. (2018). Kajian Stabilitas Keuangan No. 31. Jakarta (ID): Bank Indonesia.

Box, G. E. P., Jenkins, G. M., \& Reinsel, G. C. (2008). Time Series Analysis, Forecasting and Control 4th Edition. New Jersey (US): John Wiley \& Sons.

Boyacioglu, M. A., \& Avci, D. (2010). An adaptive network-based fuzzy inference system (ANFIS) for the prediction of stock market return: the case of the Istanbul stock exchange. Expert Systems with Applications, 37(12): 7908-7912.

Cui, H., \& Peng, X. (2015). Short-term city electric load forecasting with considering temperature effects: an improved ARIMAX model. Mathematical Problems in Engineering, 2015(589734): 1-10.

Diarsih, I., Rusgiyono, A., \& others. (2019). Modeling of red onion production in Central Java using hybrid ARIMA-ANFIS. Journal of Physics: Conference Series, 1217(1), 012080. IOP Publishing.

Faulina, R., \& Suhartono, S. (2013). Hybrid ARIMA-ANFIS for Rainfall Prediction in Indonesia. International Journal of Science and Research (IJSR), 2(2): 159-162.

Kristiana, A., Wilandari, Y., \& Prahutama, A. (2015). Peramalan Beban Puncak Pemakaian Listrik Di Area Semarang Dengan Metode Hybrid Arima (Autoregressive Integrated Moving Average)-anfis (Adaptive Neuro Fuzzy Inference System) (Studi Kasus Di PT PIn (Persero) Distribusi Jawa Tengah dan DIY). Jurnal Gaussian, 4(4): 714-723.

Lin, H.-L., Liu, L.-M., Tseng, Y.-H., \& Su, Y.-W. (2011). Taiwan's international tourism: a time series analysis with calendar effects and joint outlier adjustments. International Journal of Tourism Research, 13(1): 1-16.

Makridou, G., Atsalakis, G. S., Zopounidis, C., \& Andriosopoulos, K. (2013). Gold price forecasting with a neuro-fuzzy-based inference system. International Journal of Financial Engineering and Risk Management 2, 1(1): 35-54. 
Mariz, F. A. A. R. de. (2017). Financial inclusion and electronic payments: explaining electronic payments in Brazil with principal components analysis and Sarimax models (PhD Thesis). São Paulo (BR): Universidade de São Paulo.

Tarno, Subanar, Rosadi, D., \& Suhartono. (2013). Analysis of Financial Time Series Data Using Adaptive Neuro Fuzzy Inference System (ANFIS). International Journal of Computer Science Issues (IJCSI), 10(2): 491-496.

Tarno, T., Rusgiyono, A., Warsito, B., Sudarno, S., \& Ispriyanti, D. (2018). PEMODELAN HYBRID ARIMA-ANFIS UNTUK DATA PRODUKSI TANAMAN HORTIKULTURA DI JAWA TENGAH. MEDIA STATISTIKA, 11(1): 65-78.

Wulandari, D., Soseco, T., Narmaditya, B. S., \& others. (2016). Analysis of the use of electronic money in efforts to support the less cash society. International Finance and Banking, 3(1): 1-10.

Zhang, G. P., \& Qi, M. (2005). Neural network forecasting for seasonal and trend time series. European Journal of Operational Research, 160(2): 501-514. 